\title{
Detection and phylogenetic analysis of coastal bioaerosols using culture dependent and independent techniques
}

\author{
R. Urbano ${ }^{1}$, B. Palenik ${ }^{2}$, C. J. Gaston ${ }^{2}$, and K. A. Prather ${ }^{2,3}$ \\ ${ }^{1}$ Biological Sciences, University of California at San Diego, La Jolla, 92093, USA \\ ${ }^{2}$ Scripps Institution of Oceanography, University of California at San Diego, La Jolla, 92093, USA \\ ${ }^{3}$ Dept. of Chemistry and Biochemistry, University of California at San Diego, La Jolla, USA
}

Received: 16 July 2010 - Published in Biogeosciences Discuss.: 12 August 2010

Revised: 19 December 2010 - Accepted: 17 January 2011 - Published: 10 February 2011

\begin{abstract}
Bioaerosols are emerging as important yet poorly understood players in atmospheric processes. Microorganisms can impact atmospheric chemistry through metabolic reactions and can potentially influence physical processes by participating in ice nucleation and cloud droplet formation. Microbial roles in atmospheric processes are thought to be species-specific and potentially dependent on cell viability. Using a coastal pier monitoring site as a sampling platform, culture-dependent (i.e. agar plates) and culture-independent (i.e. DNA clone libraries from filters) approaches were combined with $18 \mathrm{~S}$ rRNA and 16S rRNA gene targeting to obtain insight into the local atmospheric microbial composition. From 13 microbial isolates and 42 DNA library clones, a total of 55 sequences were obtained representing four independent sampling events. Sequence analysis revealed that in these coastal samples two fungal phyla, Ascomycota and Basidiomycota, predominate among eukaryotes while Firmicutes and Proteobacteria predominate among bacteria. Furthermore, our culture-dependent study verifies the viability of microbes from all four phyla detected through our cultureindependent study. Contrary to our expectations and despite oceanic air mass sources, common marine planktonic bacteria and phytoplankton were not typically found. The abundance of terrestrial and marine sediment-associated microorganisms suggests a potential importance for bioaerosols derived from beaches and/or coastal erosion processes.
\end{abstract}

\section{Introduction}

Bioaerosols are abundant in the atmosphere, originating from marine and terrestrial environments. Bioaerosols include plant cell debris, pollen, fungi, microalgae, bacteria, and

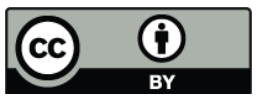

Correspondence to: B. Palenik (bpalenik@ucsd.edu) viruses. The global contribution of bioaerosols to atmospheric particles is estimated to be $1000 \mathrm{Tg} \mathrm{yr}^{-1}$ (Deguillaume et al., 2008). Over land, dry and windy conditions contribute to aerosol formation with $25-30 \%$ originating from biological sources (Morris et al., 2004; Matthias-Maser et al., 2000). In the marine atmosphere, about $10 \%$ of particulate matter by volume is attributed to biological material introduced from land and through bubble bursting at the sea surface (Matthias-Maser et al., 1999; Aller et al., 2005).

Of all bioaersols, fungi and bacteria are the best characterized. Measurements of fungal spore emissions, estimated to be $50 \mathrm{Tg} \mathrm{yr}^{-1}$, indicate that Ascomycota and Basidiomycota are major contributors to primary biological aerosols (PBA) (Elbert et al., 2007). Over terrestrial environments, bacterial PBA have been estimated to be greater than $1 \times 10^{4} \mathrm{~m}^{-3}$ (Bauer et al., 2002) with $1500 \mathrm{ml}^{-1}$ being detected in cloud droplets (Sattler et al., 2001). Overall, these studies demonstrate the abundance and diversity of biological material in the atmosphere, suggesting a potential role for bioaerosols in global climate and the hydrological cycle.

Bioaerosols are thought to influence atmospheric processes by participating in atmospheric chemistry and cloud formation. Bacteria and fungi are known to impact the organic carbon content of cloud water and aerosols through contributions of organic molecules such as mannitol, glucose, and fructose (Bauer et al., 2002; Elbert et al., 2007; Heald and Spracklen, 2009). The organic aerosol composition is important because different organic species can exert either strong positive or negative effects on the hygroscopic properties of aerosols (Saxena et al., 1995). Bioaerosols have also been shown to act as ice nuclei (IN) and, to a lesser extent, cloud condensation nuclei (CCN) (Bauer et al., 2003; Georgakopoulos et al., 2009; Möhler et al., 2007, 2008). Furthermore, Pratt et al. (2009) recently detected biological particles in situ in cloud ice residues demonstrating bioaerosol importance to cloud formation.

Published by Copernicus Publications on behalf of the European Geosciences Union. 
The ability of organisms to impact atmospheric processes might be highly species dependent since the presence of specific surface proteins has been shown to impact the efficiencies of processes such as ice crystallization (Morris et al., 2004; Möhler et al., 2007; Edwards et al., 1994; Humphreys et al., 2001). Since different organisms probably have varying ice crystal and cloud condensation capabilities, it is important to characterize PBA in different atmospheric environments to understand how and to what extent specific organisms are present.

The role of PBA in atmospheric processes is complicated by the potentially different impacts that non-viable and metabolically active microorganisms have on atmospheric processes. Metabolically active cells could directly participate in atmospheric chemistry. Previous studies suggest that a significant number of organisms are viable in clouds (Amato et al., 2007; Sattler et al., 2001; Saxena et al., 1983). Many of these microbes have been found to have important metabolic properties for degrading major cloud water organic compounds such as formate, acetate, lactate, methanol, and formaldehyde (Amato et al., 2005; Deguillaume et al., 2008). Furthermore, microbial ice nucleation has been suggested to be highly dependent on the status of cells. Proteins associated with intact cells have been suggested to be more efficient at ice nucleation than purified proteins or proteins associated with disrupted cells (Möhler et al., 2007; Morris et al., 2004). Thus not only is the phylogenetic identification of bioaerosol microbes important, but information regarding the viability and metabolic activity of these organisms is also desirable for ascertaining the role different microbes play in atmospheric processes.

Although the impact bioaerosols have on climate is becoming evident, comprehensive investigations are still needed to explore variations in microbial composition across distinct atmospheric environments. Previous work has generally relied on culture based techniques to provide insight into the viability of biological aerosols; however, limitations arise due to biases created by the narrow range of growth supported by specific media. One method of detecting organisms, without growth media biases, involves the use of molecular biology techniques on samples collected with cascade impactors. Following aerosol collection onto filters using impactors, gene targeting is performed directly on aerosol material. Airborne bacteria and fungi have been successfully characterized using $16 \mathrm{~S}$ rRNA and $18 \mathrm{~S}$ rRNA gene analysis, respectively (Nehme et al., 2008; Wu et al., 2003). A limitation to culture-independent techniques is that it does not provide information regarding cell viability. In this study, we utilize both culture-dependent and -independent techniques. Sampling was performed at a coastal monitoring pier to investigate whether coastal bioaerosols consisted of common marine planktonic microorganisms ejected from seawater or if the bioaerosols were derived from terrestrial sources.

Biogeosciences, 8, 301-309, 2011

\section{Materials and methods}

\subsection{Culture independent air sampling \& DNA isolation}

Air samples were collected on a pump house rooftop located at the end of the Scripps Institution of Oceanography (SIO) pier. The end of the pier is approximately $305 \mathrm{~m}$ from shore and $12 \mathrm{~m}$ above the ocean. Three sets of bioaerosols were collected using a 10-stage micro-orifice, uniform-deposit impactor (MOUDI) Model 110 (Applied Physics Inc.) with size cut-point diameters at 18, 10, 5.6, 3.2, 1.8, 1.0, 0.56, 0.32, $0.18,0.10$, and $0.056 \mu \mathrm{m}$ using Fluoropore membrane PTFE filters (approximately $5 \mathrm{~cm}$ in diameter) (Millipore). Sampling equipment and stages were cleaned with methanol before each sampling event. Air was drawn into the MOUDI through a stainless steel sampling mast that is $2.4 \mathrm{~m}$ in height and $2.5 \mathrm{~cm}$ in diameter. The sampling conditions of the three filter sets (Sets A-C) can be found in Table 1. Immediately after collection, the filters were stored at $-80^{\circ} \mathrm{C}$ until subsequent analysis. For Set A, DNA isolation was performed on different size cut filters, but only the 5.6-10 $\mu \mathrm{m}$ cut points yielded significant DNA amounts and showed PCR amplification when compared to control filters. Control filters were treated similarly to sampling filters, except air was not sampled; DNA extraction yielded quantities below our detection levels and PCR amplification signal was not detected. From Set B, filters with visible particulate material were selected for DNA isolation (filter size cut range 0.32-3.2 $\mu \mathrm{m}$ ), DNA was combined, and PCR was done on combined DNA. From the remaining size cuts, DNA isolation was also attempted but no significant yields were generated and PCR amplification was not detected. For Set C, particulate material was visible in filters with size cuts $0.18-0.56 \mu \mathrm{m}$; the DNA from these filters was also combined and amplified through PCR. Filters outside the $0.18-0.56 \mu \mathrm{m}$ range did not yield significant DNA and did not show PCR amplification. To isolate DNA, filters were re-suspended in TE buffer $(50 \mathrm{mM}$ Tris, $20 \mathrm{mM}$ EDTA, pH 8.0), homogenized through bead-beating, and subjected to phenol chloroform extractions and ethanol precipitation (Palenik et al., 2009). Purified DNA was quantified using Quant-it PicoGreen dsDNA Kit (Invitrogen).

\subsection{Culture-dependent air sampling and DNA isolation}

Sample set D was collected by exposing Marine Agar 2216 (Difco Laboratories Inc.) plates to air at the rooftop of the SIO Pier pump house for $0,5,10,20$, and $40 \mathrm{~min}$; the time exposures were done in duplicates, yielding a total of 10 plates. One set of plates was incubated at room temperature for 4 days while the duplicate set was first heat treated at $55^{\circ} \mathrm{C}$ for $30 \mathrm{~min}$ then incubated at room temperature for 4 days. Heat treated plates served to investigate microbes found in heat resistant forms (e.g. endospores). Subsequent analysis involved similar treatment for both sets of plates. A total of eleven bacterial colonies were picked, three of which 
Table 1. Summary of Sampling Conditions at the SIO Pier.

\begin{tabular}{|c|c|c|c|c|c|}
\hline Library ID & Control & Set A & Set B & Set $C$ & Set D \\
\hline $\begin{array}{l}\text { Date } \\
\text { (Pacific Time) }\end{array}$ & N/A & $\begin{array}{l}19 / 12 / 07(13: 00) \\
\text { to } \\
19 / 12 / 07(19: 00)\end{array}$ & $\begin{array}{l}18 / 12 / 07(18: 30) \\
\text { to } \\
19 / 12 / 07(13: 00)\end{array}$ & $\begin{array}{c}22 / 12 / 07(11: 30) \\
\text { to } \\
22 / 12 / 07(16: 30)\end{array}$ & $\begin{array}{c}18 / 06 / 2008 \\
(15: 05 \text { to } 15: 45)\end{array}$ \\
\hline Sampling rate & N/A & $31 \mathrm{lpm} *$ & $48 \mathrm{lpm}$ & $301 \mathrm{pm}$ & N/A \\
\hline $\begin{array}{l}\text { Nominal Size } \\
\text { distribution }\end{array}$ & N/A & $5.6-10 \mu \mathrm{m}$ & $0.32-3.16 \mu \mathrm{m}$ & $0.18-0.56 \mu \mathrm{m}$ & N/A \\
\hline $\begin{array}{l}\text { Collection } \\
\text { method }\end{array}$ & N/A & $\begin{array}{l}\text { Cascade } \\
\text { Impactor }\end{array}$ & $\begin{array}{l}\text { Cascade } \\
\text { Impactor }\end{array}$ & $\begin{array}{l}\text { Cascade } \\
\text { Impactor }\end{array}$ & $\begin{array}{c}\text { Plate } \\
\text { Exposure }\end{array}$ \\
\hline $\begin{array}{l}\text { DNA yield } \\
\text { or colony }\end{array}$ & $2 \mathrm{ng}$ & $35 \mathrm{ng}$ & $543 \mathrm{ng}$ & $475 \mathrm{ng}$ & $\begin{array}{c}11\left(3^{* *}\right) \\
\text { Colonies }\end{array}$ \\
\hline $\begin{array}{l}\text { Sequence } \\
\text { analysis }\end{array}$ & N/A & $18 \mathrm{~S}$ & $16 \mathrm{~S}$ & $16 \mathrm{~S}$ & $16 \mathrm{~S}, 18 \mathrm{~S}$ \\
\hline $\begin{array}{l}\text { Average Wind } \\
\text { Direction }\end{array}$ & N/A & S & SSE & WNW & $\mathrm{N}$ \\
\hline $\begin{array}{l}\text { Average Wind } \\
\text { Speed }\left(\mathrm{m} \mathrm{s}^{-1}\right)\end{array}$ & N/A & 2.5 & 2.4 & 3 & 1.64 \\
\hline $\begin{array}{l}\text { Peak Wind } \\
\text { Speed }\left(\mathrm{m} \mathrm{s}^{-1}\right)\end{array}$ & N/A & 5.54 & 6.84 & 5.81 & 3.9 \\
\hline $\begin{array}{l}\text { Air Mass } \\
\text { Back Trajectory }\end{array}$ & N/A & Oceanic & Oceanic & Continental & $\begin{array}{c}\text { Oceanic \& } \\
\text { Continental }\end{array}$ \\
\hline
\end{tabular}

${ }^{*}$ lpm: liters of air per minute; ${ }^{* *}$ analyzed from heat treated plates;

were from heat treated plates. Colonies were directly inoculated in Marine 2216 broth, incubated overnight, and DNA was isolated using the DNeasy Blood and Tissue Kit (QIAGEN). Additionally, two fungal colonies were picked, resuspended in TE buffer, and boiled for $5 \mathrm{~min}$ to lyse the cells; the boiled suspension was used for PCR. Sequencing on fungal and bacterial isolates was performed directly from $16 \mathrm{~S}$ rRNA and 18S rRNA gene PCR products.

\subsection{S rRNA gene amplification, cloning, and sequencing}

DNA from Set A clones was PCR amplified using universal eukaryotic primers, 18SFwdMV (5'ACCTGGTTGATCCTGCCAG-3') and 18SRevMV (5'-TGATCCTTCYGCAGGTTCAC-3'), near equivalent $E$. coli positions 7 and 1534 respectively (Moon-van der Staay et al., 2000). Oligonucleotides were obtained from Integrated DNA Technologies (San Diego, CA). The PCR conditions used were: $94^{\circ} \mathrm{C}$ hot start for $2 \mathrm{~min}$; 30 cycles of $30 \mathrm{~s}$ denaturation at $94^{\circ} \mathrm{C}$, annealing for $2 \mathrm{~min}$ at $52^{\circ} \mathrm{C}$, and elongations at $72^{\circ} \mathrm{C}$ for $3 \mathrm{~min}$; a final elongation at $72{ }^{\circ} \mathrm{C}$ for $10 \mathrm{~min}$. The PCR product was verified through agarose gel electrophoresis and through the absence of amplification in DNA-free controls. PCR products were cloned using the TOPO TA Cloning Kit (Invitrogen); T3 and $\mathrm{T} 7$ primers were then used to sequence the cloned fragments in both directions. Sequencing services were provided by SeqXcel Inc (San Diego, CA). Sequences were checked and assembled using Sequencher 2.0 (Gene Codes Corporation).

\subsection{S rRNA gene amplification, cloning and sequencing}

DNA from Set B and Set C was PCR amplified with universal bacterial primers, 27F (5'-AGAGTTTGATCCTGGCTCAG3') and 1492R (5'-TACGGYTACCTTGTTACGACTT-3') (Lane, 1991). The PCR conditions were: $94^{\circ} \mathrm{C}$ hot start for $3 \mathrm{~min}$; 28 cycles of $45 \mathrm{~s}$ denaturation at $94^{\circ} \mathrm{C}$, annealing for $2 \mathrm{~min}$ at $54{ }^{\circ} \mathrm{C}$, and elongation at $72^{\circ} \mathrm{C}$ for $3 \mathrm{~min}$; a final elongation was run at $72^{\circ} \mathrm{C}$ for $10 \mathrm{~min}$. Cloning, and sequencing was performed similarly to procedures described for $18 \mathrm{~S}$ rRNA gene data set.

\subsection{Phylogenetic analysis}

DNA sequences from each sample were used to obtain the top sequence match from GenBank. Using ClustalW, two alignment were constructed containing $18 \mathrm{~S}$ rRNA or $16 \mathrm{~S}$ 
NOAA HYSPLIT MODEL
a) Backward trajectories ending at 2100 UTC 19 Dec 07

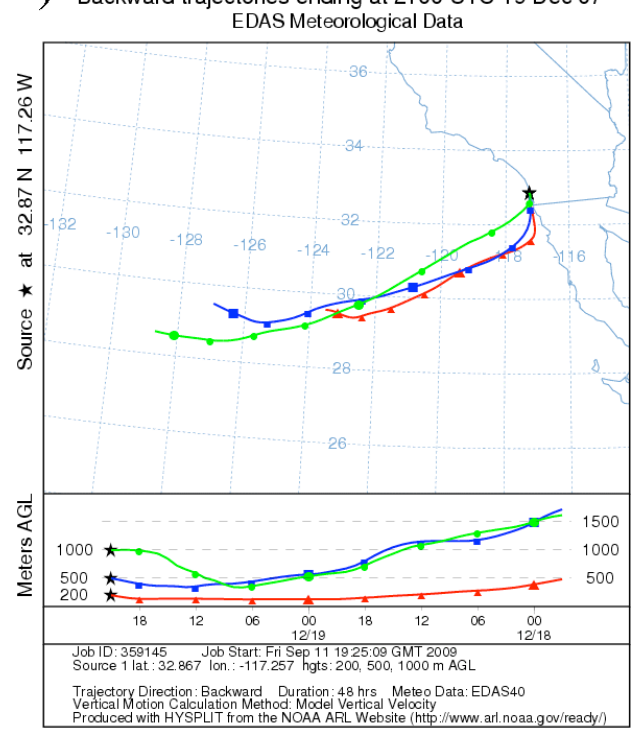

c) NOAAHYSPLIT MODEL

C) Backward trajectories ending at 0000 UTC 23 Dec 07
EDAS Meteorological Data

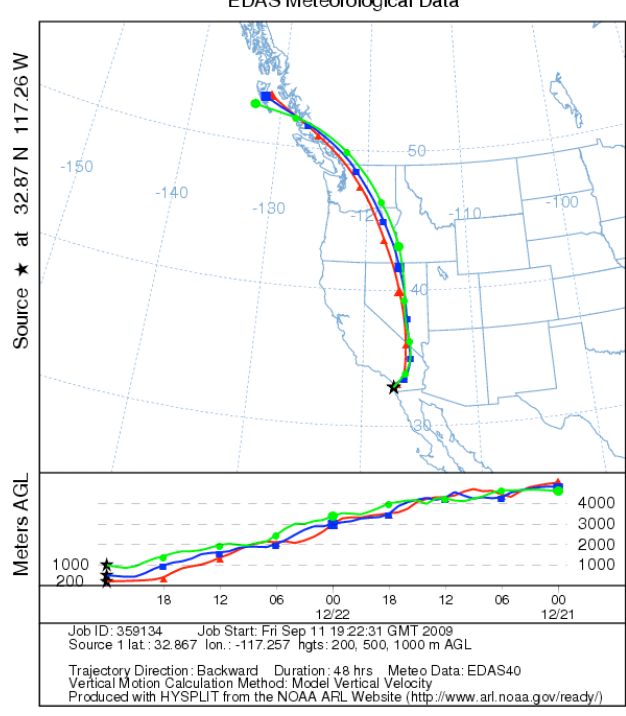

b) NOAAHYSPLIT MODEL

b) Backward trajectories ending at 1100 UTC 19 Dec 07 EDAS Meteorological Data

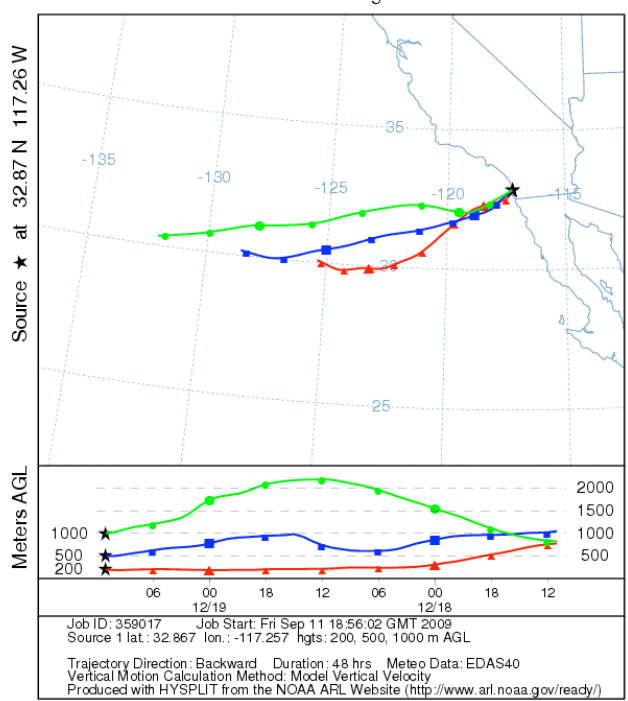

NOAA HYSPLIT MODEL
d) Backward trajectories ending at 2200 UTC 18 Jun 08

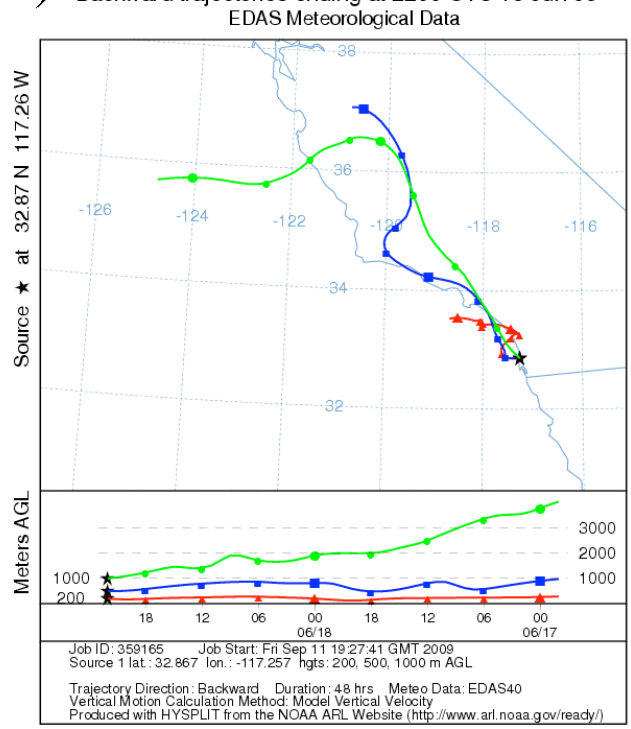

Fig. 1. Representative 48-h HYSPLIT air mass back trajectories for each filter set (A-D). Dots correspond to $6 \mathrm{~h}$ increments and lines correspond to trajectories taken at $1000 \mathrm{~m}$ (green line), $500 \mathrm{~m}$ (blue line), and $200 \mathrm{~m}$ (red line).

rRNA gene sequences and their respective top GenBank matches. The alignments were analyzed using PAUP 4.0 (Swofford, 2003) to generate distance neighbor joining trees with an HKY85 nucleotide model and accompanying bootstrap values. The $18 \mathrm{~S}$ rRNA and 16S rRNA gene trees were constructed using alignments spanning 1.138 and 1.339 nucleotides, respectively. Sequences used in trees were submitted to GenBank (accession numbers are provided in Supplementary material, Table 1).

\subsection{Air mass back trajectory analysis}

Air mass back trajectories for the four sampling events were obtained using the NOAA/HYSPLIT model 4.8 (Draxler and Rolph, 2003). Atmospheric conditions along with air mass sources (oceanic or continental) are shown in Table 1.

\section{Results}

Analysis of air mass back trajectories showed variable air mass sources for the four sampling events. Set A and B samples were collected from oceanic air masses, Set C from a 


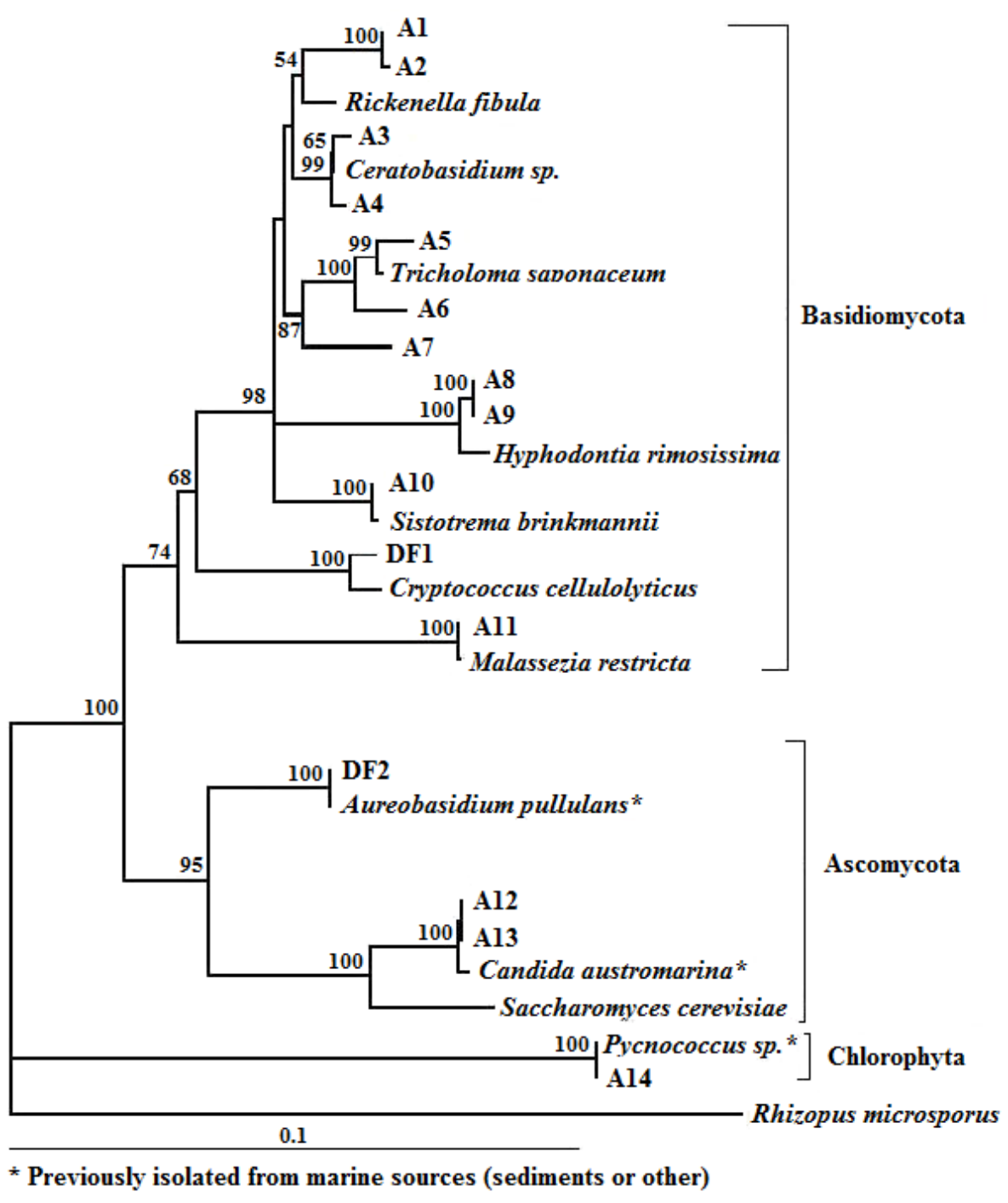

Fig. 2. A neighbor joining tree shows the phylogenetic relationships among our $18 \mathrm{~S}$ rRNA environmental clones, plate isolates, and their top sequence matches obtained through NCBI BLAST. The distance tree is based on a sequence alignment spanning over a 1.138 nucleotide region of the 18S rRNA gene and is rooted with $R$. microsporus. The distances were calculated using the HKY 85 nucleotide model. The bootstrap analysis was done using 100 replicates.

continental air mass, and Set D from a mixed continentaloceanic air mass (Fig. 1). Regardless of air mass sources, the four data sets detected similar microorganisms.

Phylogenetic analysis of 16 eukaryotic sequences (Set A), collected through culture-dependent and -independent techniques, showed a predominance of the Ascomycota and $\mathrm{Ba}-$ sidiomycota fungal phyla (Fig. 2). Chlorophyta was the only non-fungal sequence detected. Ascomycota sequences were closely related to Aureobasidium pullulans and Candida austromarina, while Basidiomycota closely matched the genera Rickenella, Ceratobasidium, Tricholoma, Hyphodontia, Systotrema, Cryptococcus, and Malassezia. Consistent with the MOUDI approach, samples collected using Marine 2216 plate media revealed the presence of the Ascomycota and Ba- sidiomycota fungal phyla (Set D; isolates DF2 and DF1, respectively), although these were not similar to clones in the 18S rRNA gene clone library.

Phylogenetic analysis of 39 prokaryotic sequences (Set B, C, D) revealed the presence of two major bacterial phyla, Firmicutes and Proteobacteria (Fig. 3). Among the prokaryotic data sets, 18 sequences belonged to Firmicutes, 17 to Proteobacteria, 2 to Actinobacteria, and 2 were unknown. Bacillus, Geobacillus, and Paenibacillus, were highly represented among the Firmicutes, but other genera such as Oceanobacillus were also detected. Among Proteobacteria, Rastolnia was the most abundant but a single sequence each of Brevundimonas, Roseococcus, and Paracoccus was also detected. Sequences highly related to Ralstonia pickettii were common 


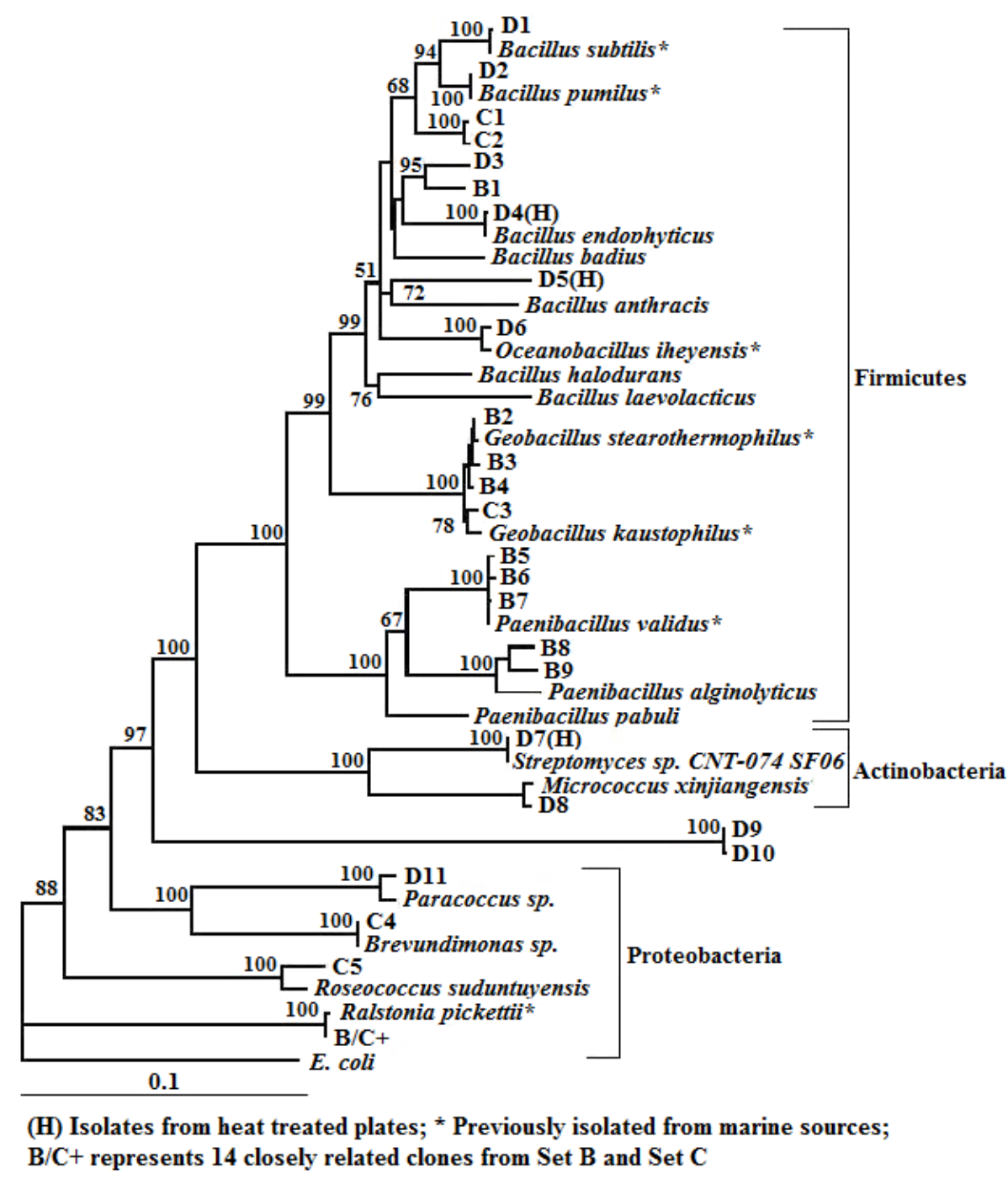

Fig. 3. A neighbor joining tree shows the phylogenetic relationships among our environmental clone library sequences, plate colony sequences, and their top sequence matches obtained through NCBI BLAST. The distance tree is based on a sequence alignment spanning over a 1.339 nucleotide region of the 16S rRNA gene and is rooted with Escherichia coli. The distances were calculated using the HKY85 nucleotide model. The bootstrap analysis was done using 100 replicates.

in Set B and Set C (Fig. 3; "B/C+" represent 14 Ralstonia clones). Ralstonia sequences showed little sequence diversity and had a sequence match of $\geq 99 \%$ identity. Although we did not detect PCR amplification in our DNA-negative controls, the presence of Ralstonia in bioaerosols should be treated with caution. Ralstonia is known to be found in ultrapure water systems (Kulakov et al., 2002). The two Actinobacteria detected closely matched the Streptomyces and Micrococcus genera.

The 13 isolates collected through Marine 2216 plates (Set D) were viable and grew to produce colonies. Since both fungal and bacterial isolates were similar to the most abundant clones in our environmental DNA libraries, a significant number of the detected microorganisms might be found in viable states. Colonies could have developed from vegetative cells or through spore germination. However, our heat treated plates inhibited all fungal growth but did show the eventual growth of some bacteria. Known spore formers, Bacillus and Streptomyces species, were among the heat resistant isolates (Fig. 3, heat treatment indicated by $(\mathrm{H})$ ).

Many of the observed fungal and bacterial sequences are from taxa commonly found in soils and other terrestrial sources. However, some of the identified taxa are likely of marine origin (Figs. 2 and 3, marine indicated by *). The microalgae Pycnococcus sp. and the marine yeasts Aerobasidium pullulans and Candida austromarina are commonly found in marine environments (Guillard et al., 1991; Campbell et al., 1994; Gao et al., 2009; Chi et al., 2007; Fell and 
Hunter, 1974). Previous studies have also found many bacteria related to B. subtilis, B. pumilus, Paenibacillus, and R. pickettii, in marine environments (Siefert et al., 2000; Brück et al., 2007). Many other bacteria have been isolated from deep sea sediments and include the genera Streptomyces, Oceanobacillus, and Geobacillus (Prieto-Davó et al., 2008; Takami et al., 2002, 2004).

\section{Discussion}

Fungi were the primary eukaryotic organisms found as aerosols at the SIO Pier. These result are similar to previous studies that report high numbers of Ascomycota and Basidiomycota in bioaerosols and cloud water (Elbert et al., 2007; Després et al., 2007; Amato et al., 2005, 2007). Most of the fungal genera detected, including Tricholoma, Hyphodontia, Sistotrema, Cryptococcus, Aurobasidium, and Candida, were found in a recent year-long study conducted over a continental air mass in Germany (Fröhlich-Nowoisky et al., 2009). Despite this, our fungal 18S rRNA sequences were not particularly close at the species level to those seen previously. This highlights the general presence but likely high diversity of Ascomycota and Basidiomycota in the atmosphere.

Firmicutes and Proteobacteria were the predominant bacteria detected in our air samples. These results are in agreement with studies that have found Streptomyces, Micrococcus, Bacillus, Paenibacillus and many Proteobacteria associated with continental air and cloud water (Després et al., 2007; Amato et al., 2005, 2007). Of particular similarity is the recent report by Maki et al. (2010), which shows Bacillus in association with high altitude dust events. In contrast to our study, Fahlgren et al. (2010) recently reported a bacterial dominance by the Sphingomonas and Pseudomonas genera. The abundance of specific microbes in the air is probably influenced by the microbial distributions in surrounding environments, the specific microbial characteristics that might facilitate emission into the atmosphere (e.g. spores), and the physical mechanisms of aerosol formation that are at play (e.g. wind). Nevertheless, there seems to be a ubiquity of specific bacteria across different atmospheric environments particularly Bacillus related genera.

The common presence of fungi and Bacillus-related bacterial species suggests that spores or spore forming microorganisms might be regularly more abundant in the atmosphere. Sporogenesis is well known to add to the dynamics of these ubiquitous organisms allowing them to better deal with environmental stress and probably to cycle between land, air, and aquatic environments. In our study we found a high number of potentially spore forming bacteria (i.e. Bacillus and Streptomyces) (Onyenwoke et al., 2004; Hardisson and Manzanal, 1976). Although there is an important correlation between spores and aerosols, it is critical to mention that the presence of non-spore forming bacteria (e.g. M. xinjiangensis, Paracoccus sp., Brevundimonas sp., R. suduntuyensis, and $R$. pickettii) in our samples and other studies indicates that spores are not essential for air transit.

In our samples, we did not find any fungi or bacteria well known for being efficient in ice or cloud nucleation, although such studies have not been exhaustive.

Contrary to our expectations that oceanic air masses would lead to PBA dominated by planktonic marine bacteria and phytoplankton, we did not find these dominating the biotic particles of our coastal sampling site. Although our sample sizes are relatively small, common marine bacterial taxa (Pelagibacter, Roseobacter, Synechococcus, etc.) including those commonly found in marine waters near the SIO pier (Mayali et al., 2010) were not found among our samples. Although we detected a Pycnococcus-related species, no other members of the eukaryotic ultraplankton such as diatoms or dinoflagellates were identified. One explanation for the lack of planktonic marine microbes but the finding of marine fungi and sediment associated Bacillus species is that local beaches, with regular wetting, drying, and wave action may serve as a source of bioaerosols to coastal environments. Since sandy beaches are ubiquitous in the world, they may represent an unappreciated source of global bioaerosol production.

\section{Supplementary material related to this article is available online at: http://www.biogeosciences.net/8/301/2011/ bg-8-301-2011-supplement.pdf.}

Acknowledgements. We gratefully acknowledge the NOAA Air Resources Laboratory for the provision of the HYSPLIT transport model and READY website (http://ready.arl.noaa.gov/) used in this publication. Assistance with sampling and molecular methods was kindly provided by McKell Gregory, Vera Tai, and Rhona Stuart. Funding was provided by United States National Science Foundation (MCB0731771).

Edited by: G. Herndl

\section{References}

Aller, J. Y., Kuznetsova, M. R., Jahns, C. J., and Kemp, P. F.: The sea surface microlayer as a source of viral and bacterial enrichment in marine aerosols, J. Aerosol Sci., 36, 801-812, 2005.

Amato, P., Ménager, M., Sancelme, M., Laj, P., Mailhot, G., and Delort, A.-M.: Microbial population in cloud water at the Puy de Dôme: implications for the chemistry of clouds, Atmos. Environ., 39, 4143-4153, 2005.

Amato, P., Parazols, M., Sancelme, M., Laj, P., Mailhot, G., and Delort, A. M.: Microorganisms isolated from the water phase of troposheric clouds at the Puy de Dôme: major groups and growth abilities at low temperatures, FEMS Microbiol. Ecol., 59, 242254, 2007.

Bauer, H., Kasper-Giebl, A., Löflund, M., Giebl, H., Hitzenberger, R., Zibuschka, F., and Puxbaum, H.: The contribution of bacteria 
and fungal spores to the organic carbon content of cloud water, precipitation and aerosols, Atmos. Res., 64, 109-119, 2002.

Bauer, H., Giebl, H., Hitzenberger, R., Kasper-Giebl, A., Reischl, G., Zibuschka, F., and Puxbaum, H.: Airborne bacteria as cloud condensation nuclei, J. Geophys. Res-Atmos., 108 (D21), 4658, doi:10.1029/2003JD003545, 2003.

Brück, T. B., Brück, W. M., Santiago-Vázquez, L. Z., McCarthy, P. J., and Kerr, R. G.: Diversity of the bacterial communities associated with the Azooxanthellate deep water octocorals Leptogorgia minimata, Iciligorgia schrammi, and Swiftia exertia, Mar. Biotechnol., 9, 561-576, 2007.

Campbell, L., Shapiro, L. P., and Haugen, E.: Immunochemical characterization of eukaryotic ultraplankton from the Atlantic and Pacific Oceans, J. Plankton Res., 16 (1), 35-51, 1994.

Chi, Z., Ma, C., Wang, P., and Li, H. F.: Optimization of medium and cultivation conditions for alkaline protease production by the marine yeast Aureobasidium pullulans, Bioresource Technol., 98, 534-538, 2007.

Deguillaume, L., Leriche, M., Amato, P., Ariya, P. A., Delort, A.M., Pöschl, U., Chaumerliac, N., Bauer, H., Flossmann, A. I., and Morris, C. E.: Microbiology and atmospheric processes: chemical interactions of primary biological aerosols, Biogeosciences, 5, 1073-1084, doi:10.5194/bg-5-1073-2008, 2008.

Després, V. R., Nowoisky, J. F., Klose, M., Conrad, R., Andreae, M. O., and Pöschl, U.: Characterization of primary biogenic aerosol particles in urban, rural, and high-alpine air by DNA sequence and restriction fragment analysis of ribosomal RNA genes, Biogeosciences, 4, 1127-1141, doi:10.5194/bg-4-1127-2007, 2007.

Draxler, R. R. and Rolph, G. D.: HYSPLIT (Hybrid Single-Particle Lagrangian integrated Trajectory) model, (http://ready.arl.noaa. gov/HYSPLIT.php), NOAA Air Resources Laboratory, Silver Spring, MD, 2003.

Edwards, A. R., Van den Bussche, R. A., Wichman, H. A., and Orser, C. S.: Unusual pattern of bacterial ice nucleation gene evolution, Mol. Biol. Evo., 11(6), 911-920, 1994.

Elbert, W., Taylor, P. E., Andreae, M. O., and Pöschl, U.: Contribution of fungi to primary biogenic aerosols in the atmosphere: wet and dry discharged spores, carbohydrates, and inorganic ions, Atmos. Chem. Phys., 7, 4569-4588, doi:10.5194/acp-7-4569-2007, 2007.

Fahlgren, C., Hagström Å., Nilsson, D., and Zweifel U. L.: Annual variations in the diversity, viability, and origin of airborne bacteria, Appl. Environ. Microb., 3015-3025, 76, 2010.

Fell, J. W. and Hunter, I. L.: Torulopsis austromarina sp, nov. A yeast isolated from the Antarctic Ocean, Anton. Leeuw. Int. J. G., 40, 307-310, 1974.

Fröhlich-Nowoisky, J., Pickersgill, D. A., Després, V. R., and Pöschl, U.; High diversity of fungi in air particulate matter, P. Natl. Acad. Sci. USA, 106, 12814-12819, 2009.

Gao, Z., Johnson, Z. I., and Wang, G.: Molecular characterization of the spatial diversity and novel lineages of mycoplankton in Hawaiian coastal waters, ISME J., 1751-7362, 2009.

Georgakopoulos, D. G., Després, V., Fröhlich-Nowoisky, J., Psenner, R., Ariya, P. A., Pósfai, M., Ahern, H. E., Moffett, B. F., and Hill, T. C. J.: Microbiology and atmospheric processes: biological, physical and chemical characterization of aerosol particles, Biogeosciences, 6, 721-737, doi:10.5194/bg-6-721-2009, 2009.

Guillard, R. R. L., Keller, M. D., O'Kelly, C. J., and Floyd, G. L.: Pycnococcus provasolii gen. et sp. nov., a coccoid prasinoxanthin-containing phytoplankter from the western north Atlantic and Gulf of Mexico, J. Phycol., 27, 39-47, 1991.

Hardisson, C. and Manzanal, M. B.: Ultrastructural studies of sporulation in Streptomyces, J. Bacteriol., 127, 1443-1454, 1976.

Heald, C. L. and Spracklen, D. V.: Atmospheric budget of primary biological aerosol particles from fungal spores, Geophys. Res. Lett., 36, L09806, doi:10.1029/2009GL037493, 2009.

Humphreys, T. L., Castrillo, L. A., and Lee, M. R.: Sensitivity of partially purified ice nucleation activity of Fusarium acuminatum SRSF 616, Curr. Microbiol., 42, 330-338, 2001.

Kulakov, L. A., McAlister, M. B., Ogden, K. L., Larkin, M. J., and O'Hanlon, J. F.: Analysis of bacteria contaminating ultrapure water in industrial systems, Appl. Environ. Microb., 68, 1548$1555,2002$.

Lane, D. J.: 16S/23S rRNA sequencing, in: Nucleic acid techniques in bacterial systematics, edited by: Stackebrandt, E. and Goodfellow, M., Wiley and Sons, Chichester, UK, 115-175, 1991.

Maki, T., Susuki, S., Kobayashi, F., Kakikawa, M., Tobo, Y., Yamada, M., Higashi, T., Matsuki, A., Hong, C., Hasegawa, H., and Iwasaka, Y.: Phylogenetic analysis of atmospheric halotolerant bacterial communities at high altitude in an Asian dust (KOSA) arrival region, Suzu City, Sci. Total Environ., 408, 4556-4562, 2010.

Matthias-Maser, S., Brinkmann, J., and Schneider, W.: The size distribution of marine atmospheric aerosol with regard to primary biological particles over the South Atlantic Ocean, Atmos. Environ., 33, 3569-3575, 1999.

Matthias-Maser, S., Obolkin V., Khodzer, T., and Jaenicke, R.: Seasonal variations of primary biological aerosol particles in the remote continental region of Lake Baikal/Siberia, Atmos. Environ., 32, 3805-3811, 2000.

Mayali, X., Palenik, B., and Burton, R. S.: Dynamics of marine bacterial and phytoplankton populations using multiplex liquid bead array technology, Environ. Microbiol., 12 (4), 974-989, 2010.

Möhler, O., DeMott, P. J., Vali, G., and Levin, Z.: Microbiology and atmospheric processes: the role of biological particles in cloud physics, Biogeosciences, 4, 1059-1071, doi:10.5194/bg-4-10592007, 2007.

Möhler, O., Georgakopoulos, D. G., Morris, C. E., Benz, S., Ebert, V., Hunsmann, S., Saathoff, H., Schnaiter, M., and Wagner, R. Heterogeneous ice nucleation activity of bacteria: new laboratory experiments at simulated cloud conditions, Biogeosciences, 5, 1425-1435, doi:10.5194/bg-5-1425-2008, 2008.

Moon-van der Staay, S. Y., van der Staay, G. W. M., Guillou, L., and Vaulot, D.: Abundance and diversity of prymnesiophytes in the picoplankton community from the equatorial Pacific Ocean inferred from 18S rDNA sequences, Limnol. Oceanogr., 45, 98 109, 2000.

Morris, C. E., Georgakopoulos, D. G., and Sands, D. C.: Ice nucleation active bacteria and their role in precipitation, J. Phys. IV France, 121, 87-103, 2004.

Nehme, B., Letourneau, V., Forster, R., Veillette, M., and Duchaine, C.: Culture-independent approach of the bacterial bioaerosol diversity in the standard swine confinement buildings, and assessment of the seasonal effect, Environ. Microbiol., 10, 665-675, 2008.

Onyenwoke, R. U., Brill, J. A., Farahi, K., and Wiegel, J.: Sporulation genes in members of the $\mathrm{G}+\mathrm{C}$ Gram-type-positive phylogenetic branch (Firmicutes), Arch. Microbiol., 182, 182- 
192, 2004.

Palenik, B., Ren, Q., Tai, V., and Paulsen, I. T.: Coastal Synechococcus metagenome reveals major roles for horizontal gene transfer and plasmids in population diversity, Environ. Microbiol., 11, 349-359, 2009.

Pratt, K. A., DeMott, P. J., French, J. R., Wang, Z., Westphal, D. L., Heymsfield, A. J., Twohy, C. H., Prenni, A. J., and Prather, K. A.: In situ detection of biological particles in cloud ice-crystals, Nature Geoscience, 2, 397-400, 2009.

Prieto-Davó, A., Fenical, W., and Jensen P. R.: Comparative actinomycete diversity in marine sediments, Aquat. Microb. Ecol., 52, 1-11, 2008.

Sattler, B., Puxbaum, H., and Psenner, R.: Bacterial growth in supercooled cloud droplets, Geophys. Res. Lett., 28, 239-242, 2001.

Saxena, V. K.: Evidence of the biogenic nuclei involvement in Antarctic coastal clouds, J. Phys. Chem., 87, 4130-4134, 1983.

Saxena, P., Hildemann, L. M., McMurray, P. H., and Seinfeld, J. H.; Organics alter hygroscopic behavior of atmospheric particles, J. Geophys. Res., 100(9), 18755-18770, 1995.
Siefert, J. L., Larios-Sanz, M., Nakamura, L. K., Slepecky, R. A., Paul, J. H., Moore, E. R. B., Fox, G. E., and Jurtshuk, P. Jr.: Phylogeny of marine Bacillus isolates from the Gulf of Mexico, Curr. Microbiol., 41, 84-88, 2000.

Swofford, D. L.: PAUP*. Phylogenetic Analysis Using Parsimony (*and Other Methods), Version 4. Sinauer Associates, Sunderland, Massachusetts, 2003.

Takami, H., Takaki, Y., and Uchiyama, I.: Genome sequence of Oceanobacillus iheyensis isolated from the Iheya Ridge and its unexpected adaptive capabilities to extreme environments, Nucleic Acids Res., 30, 3927-3935, 2002.

Takami, H., Nishi, S., Lu, J., Shimamura, S., and Takaki Y.: Genomic characterization of thermophilic Geobacillus species isolated from the deepest sea mud of the Mariana Trench, Extremophiles, 8, 351-356, 2004.

Wu, Z., Tsumura, Y., Blomquist, G., and Wang, X.-R.: 18S rRNA gene variation among common airborne fungi, and development of specific oligonucleotide probes for the detection of fungal isolates, Appl. Environ. Microb., 69, 5389-5397, 2003. 